\title{
The Structure of Labor Markets in the US and China: Social Capital and Guanxi
}

\author{
Nancy DiTomaso ${ }^{1}$ and Yanjie Bian ${ }^{2,3}$ \\ ${ }^{1}$ Rutgers University, USA, ${ }^{2}$ University of Minnesota, USA, and ${ }^{3}$ Xi'an fiaotong University, China
}

ABSTRACT Despite the major cultural and political differences between the United States and China, in both countries access to jobs is supposed to be guided by fair and equitable procedures. In the US, there is a presumption of an open labor market in which potential employees compete on the basis of their qualifications, where the fairness of decisions is guided by anti-discrimination laws and normative organizational policies. In China, although there is a history of close relationships that guide the exchange of favors, following the 1949 revolution, Communist Party leaders were given the authority to allocate positions in ways that were supposed to eliminate special privileges of class and background. Yet recent research has suggested that social connections are an important part of getting a job in both the US and China for two-thirds to three-quarters of job seekers. In the US context, such connections are described as social capital. In the Chinese context, connections are defined as guanxi. In this article, we review research on labor market processes in both the US and China to address three important questions: (a) How can we understand the similar functioning of labor markets in such distinct cultural and political systems as the US and China? (b) What are the mechanisms or processes by which people find jobs in the US and China, and how are people able to access these mechanisms or processes in the context of constraining social structures and legal environments? and (c) What are the theoretical implications of the 'generalized particularism' that seems to shape labor markets in both the US and China.

KEYWORDS guanxi, labor markets, social capital, social networks

\section{INTRODUGTION}

Personal choices and relations in China, a socialist country at early stages of industrialization and economic development, seem to be remarkably similar to those in the United States, a capitalist country at advanced stages, quite possibly because particularism governs personal relations regardless of cultural, political, or economic differences. (Blau, Ruan, \& Ardelt 1991: 1037) 
Since Blau et al. (1991) called attention to the universal nature of particularism in contrasting the US and China, research on labor market processes in both countries has found empirical evidence of their claims (Bian \& Huang, 2016; Bian, In Press; DiTomaso, 2013). Particularism by use of social networks in the job search process has become a major theme in the research on inequality in both the US and China (Lin, 1999b; Lin, Fu, \& Chen, 2013). Research, both independently on each country and comparatively between the two countries, has found that social networks (termed social capital in the US context and guanxi in the Chinese one) play major roles in how people find jobs in each country, despite legal, political, social, economic, and cultural differences between the two countries. In this article, we review research evidence that shows that in both the US and China most jobs are obtained through social connections or networks in ways that underline the particularism that functions in both countries when it comes to gaining access to valuable resources like jobs.

The fact of network influence on finding jobs is well known across many social contexts (Bayer, Ross, \& Topa, 2008; Brown, Setren, \& Topa, 2016; Burks, Cowgill, Hoffman, \& Housman, 2015; Cingano \& Rosolia, 2012; Hellerstein, McInerney, \& Neumark, 2011; Loury, 2006; Schmutte, 2016a; Sharone, 2014). In this article, we want to highlight some of the similarities and differences between the labor market processes in the US and China to raise important theoretical points. Specifically, we ask three major questions: (a) How can we understand the similar functioning of labor markets in such distinct cultural and political systems as the US and China? (b) What are the mechanisms or processes by which people find jobs in the US and China, and how are people able to access these mechanisms or processes in the context of constraining social structures and legal environments? and (c) What are the theoretical implications of the 'generalized particularism' that seems to shape labor markets in both the US and China.

\section{The Gultural and Political Differences Between the US and China}

In any discussion about cross-cultural differences, the US and China are often compared as representing the West and the East, and more generally, as characterizing the most distinct cultural differences (Cuddy, Fiske, \& Glick, 2008; Gelfand, Erez, \& Aycan, 2007; Hofstede, 1997; Kitayama, 2002; Nisbett, 2003; Tsui, Nifadkar, \& Ou, 2007). The US is a capitalist country, while China is communist. The US has a democratic system of government, while in China the Communist Party has legal control based on the constitution. Although multiculturalism exists in both countries, the US is primarily a Christian nation, while Chinese culture is strongly influenced by Confucianism. Indeed, there are major differences in the cultures and the political systems of the US and China.

US culture is extremely individualistic, whereas Chinese culture is collectivist (Hofstede, 1984; Triandis, 1995). Upbringing in the US strives to teach independence, whereas in China interdependence is valued (Markus \& Kitayama, 
1991). The individualism of US culture creates a conception of people as atomistic or separate from each other. In the US, self-sufficiency is highly valued. In contrast, Chinese culture is more relational (Brewer \& Chen, 2007). People are thought of in reference to the social groups to which they belong, and there is a cultural expectation of mutual obligation among the group members to which one is tied (Bian \& Logan, 1996; Markus \& Kitayama, 1991). Such cultural differences also affect communication styles, with US culture utilizing what is called low context communication, where it is assumed that understanding comes only by saying explicitly what one wants the other person to know. In contrast, in Chinese culture, communication is high context, meaning that there is a great deal of understanding without the use of words, because people know a lot about others by knowing the context of their relationships (Hall, 1959; Kipnis, 1997). Nisbett et al. (2001) also argue that cultural differences between the West and the East affect modes of thinking, with Western culture more analytical and Eastern culture more dialectical in thinking patterns.

Thus, the cultural distinctions between the US and China create profiles of preferred ways of thinking and behaving that form polar opposites: Americans are individualist, independent, self-sufficient, and act on their own. The Chinese are collectivist, interdependent, embedded in strong relationships that shape behavior, and act as members of a group sharing mutual obligations. Moral behavior within the US tends to be guided by an ethics of not doing harm, whereas moral behavior within China tends to be guided by the fulfillment of obligations to others within close social groups.

In addition to the stark contrasts in the cultural assumptions between the US and China, the political systems of the US and China are also often thought of as polar opposites. In the democratic system within the US, citizens vote for political leaders at each level of government, and such leaders are expected to develop laws and policies that serve the interests of their constituents and that reflect their preferences. Although there are many and extensive critiques about the gap between theory and practice in US politics - and wide divergences as well about what should constitute proper representation depending on political party affiliation and personal interests - there is no question that democratic processes are more active and meaningful in the US than they are in China, which in the post-Mao era is still a one-party state, with political leaders at all levels chosen by the Communist Party. While there have been major changes in Chinese society since a series of reforms were introduced in 1978, there is no pretense in China that the population can vote to change their leaders and establish substantially different policies than those approved by the Communist Party.

Within the democratic system of the US and the command structure of the Chinese government, both culture and politics affect the functioning of labor markets, but in the one case by interfering with markets, while in the other case, interfering with state planning. In the US, despite assumptions that people freely compete for jobs in an open labor market, evidence suggests that there are 
many mechanisms by which those who have access to social resources endeavor, whenever possible, to avoid market competition and to gain an inside edge in finding jobs (Castilla, 2005; DiTomaso, 2013; Fernandez, Castilla, \& Moore, 2000; Lin \& Bian, 1991; Lin, Ensel, \& Vaughn, 1981; Marsden \& Hurlbert, 1988). In China, research has yet to settle how much influence in the post-reform period (i.e., post-1978) that political leaders retain in the decisions about who has access to jobs (Bian, 1997, 2002; Bian \& Huang, 2015; Bian, Huang, \& Zhang, 2015; Cao \& Nee, 2000; Nee, 1996; Tian \& Lin, 2016; Zhao, 2013), but there is agreement that guanxi still operates, and the most recent evidence suggests that it does so at a high level in the job finding process (Bian, In Press). In a sense, the US and China have arrived at similar places from opposite directions. The US is supposedly a market-based system, but the US labor market is heavily influenced by non-market efforts to gain advantage and avoid market competition on the part of most job seekers. China is a country in transition that through its revolution endeavored to eliminate or constrain the use of family and friendship connections to gain social resources, but as more jobs are emerging outside the state sector and more market competition is being introduced, it appears that there has been increased use of the particularistic ties of guanxi to gain access to jobs, both within the state sector through ties to cadre leaders and outside of it through influence networks based on kin and kin-like relationships (Bian, In Press). Thus, in the US social connections arise in the movement away from functioning markets, whereas in China, social connections arise in the movement toward markets.

As we will outline below, in the well-developed labor market of the US and in the emergent labor market of the Chinese hybrid system, two-thirds to threequarters of jobs appear to be found with the help of social connections. Although Blau et al. (1991) characterize these outcomes as particularism that perhaps is an outgrowth of human nature, it seems more likely that reliance on social networks in the context of inequality reflects the efforts by job seekers in both countries to gain advantage and to avoid competition. In the US, the market supposedly dominates but is often undermined (DiTomaso, 2013). In pre-reform China, state planning supposedly dominated the job search process, but the role of state planning was challenged by the influence of guanxi (Bian \& Ang, 1997; Walder, 1986). In reformera China, emerging markets supposedly rationalize job markets to get rid of guanxi influence (Guthrie, 1998), but they never really did so (Bian, In Press; Yang, 2002). Thus, in reality, the job search processes in both the US and China take place within hybrid systems that are shaped by the contours of social inequality, and thus in both countries, social connections are growing in importance in the job search process and seemingly play a far more prominent role than is often acknowledged.

In both countries, the use of social connections involves drawing on the good will and sense of obligation of those like oneself who are positioned to help, not so much because of natural sentiment, as it is because of the structure of unequal social relationships in which some have greater access to social resources than others (Lin, 
1999b). The segregation of race and ethnic groups in the US reinforces the ingroup solidarity that contributes to whites primarily helping other whites in the job search process (Alexander et al., 2014; DiTomaso, 2013; Massey, 2007; Royster, 2003; Smith, 2002) and to nonwhites to helping members of their own groups as well. Whites, however, have structural advantages that make their help more efficacious than is the case for nonwhites. In China, there are privileges for urban workers over those consigned to rural areas (Liang, Appleton, \& Song, 2016), professional and managerial workers have regained privileges compared to manual workers (Walder, Luo, \& Wang, 2013), and those connected to the party retain special privileges compared to those who are not party members (Bian \& Logan, 1996).

The exchange of favors among members of dominant groups contributes to their stronger position within the system of stratification in each country, and it enables in both the specific instances of quid pro quo and the more generalized instances of community-regarding favors to reproduce inequality over time. While there are contingencies that may affect how much influence social connections have for any given position, such as the tightness or looseness of the labor market, asymmetry in information and authority, the skill requirements of the job, and the extent to which there are laws or regulations that constrain the choices of those who do the hiring, it seems that many if not most jobs, in both China and the US are overlaid with the influences of social connections. While the institutionalization and the everyday practices of social systems shape how people in a given society search for jobs and gain access to them, we find that people use social connections when they are available to them and when they can find ways to gain an inside edge to gain access to scarce social resources.

\section{Social Ties in the US and Ghina: Social Capital and Guanxi}

Our first research question, therefore, is how can we understand the similar functioning of labor markets in the US and China, given such differences between the two countries? To answer this question, we need to review how social ties work in both the US and China, and then how labor markets work in both countries. It is noteworthy that in both the US and China, there is an ambivalent attitude toward the use of social ties to gain advantages in the labor market, because in both countries, there is, at some level, a recognition that the use of personal ties to avoid competition will affect inequality (Schmutte, 2016a). Yet in both the US and China, job seekers are regularly given advice to use networks whenever they can. On the one hand, the use of network ties is considered an important pathway to achieving success, and thus, understanding how to develop such ties and how to use them are considered skills to be developed (Baker, 1994, 2000). On the other hand, there is a sense in which the use of social ties to gain advantages that are not available to others is considered to be unfair or perhaps even illicit (Boisot \& Child, 1996; Chen \& Chen, 2008; Elliott, 1999; Ibarra, 1995; Royster, 2003; Schneider et al., 1997; Seidel, Polzer, \& Stewart, 2000). 
In the US context, drawing from the work of Bourdieu (1986), the research on social connections or ties uses the metaphor of 'social capital'; (Adler \& Kwon, 2002; Burt, 1997; Lin, 1999b, 2001b; Portes, 1998; Putnam, 2000). In China, the term guanxi describes the close social relationships that guide the exchange of favors (Bian, 1994; Bian, In Press; Chen, Chen, \& Huang, 2013; Guthrie, 1998; Tsui \& Farh, 1997; Yang, 2002). Bourdieu (1986: 248) defines social capital as: 'the aggregate of the actual or potential resources which are linked to possession of a durable network of more or less institutionalized relationships of mutual acquaintance or recognition'. Social connections or social networks are assumed to involve exchanges that are valuable for each member of the network (Cook et al., 1983; DiTomaso, 2013; Mizruchi \& Stearns, 2002; Uzzi, 1999). Such exchanges, however, differ in terms of when and how benefits are received and from whom.

Putnam (2000) differentiates between specific reciprocity in which there is a quid pro quo and an explicit expectation of receiving a favor from the person to whom one was given and generalized reciprocity which exists within a community without an expectation of a defined exchange. In generalized reciprocity, goodwill exists among members of the community, who then do things that are of value for the community as a whole, on the expectation that it will strengthen the social group and benefit all group members mutually. Coleman (1988) argues that this sort of generalized reciprocity or generalized social capital improves the quality of life within a community or group. For example, according to Coleman (1988) the exchange of social capital can make it possible to trust others in the community to follow collective norms, can create a safe environment for children and community members to interact freely with each other, and can induce an expectation that members of the community will look out for each other. Indeed, Burt and Burzynska (2017) argue that the association between trust and closed social networks characteristic of generalized reciprocity is one of two key findings within the literature on social capital. In contrast, specific reciprocity occurs in an exchange of favors in which there is a quid pro quo expectation, although in both the US and China, such exchanges can be overlaid with sentiment and a sense of moral obligation that removes the exchange from a purely instrumental connection (Lo \& Otis, 2003). Generalized social capital is exchanged for the good of the community; specific social capital is exchanged for the good of the parties involved. But even within specific social capital, there can be third party ties that facilitate the relationship and the exchange, and the favors that are exchanged need not be material and need not be simultaneous in time.

Social, cultural, and financial capital in the US exists within the context of social relationships that are both generalized and specific and seem to be based more often on weak ties than on strong ties (Granovetter, 1973; Lin, 1982) compared to those in China (Bian, 1997). Such relationships, though, have boundaries that define who is in the group and who is out. The exchange of social resources among members of a group requires trust, among other things, because the exchanges 
are made with the expectation that they will improve or strengthen the group or that benefits will be forthcoming from group members at some future point. The social resources that are exchanged, therefore, are valuable but limited, in the sense that they would become less valuable if they were offered too widely or too often. Further, because receiving social resources in the present carries with it the obligation to provide social resources at some point in the future, one has to be willing to incur future social obligations in the process of gaining access to social resources from others that may be needed in the present.

In neither the US nor China is there a strict accounting of the value of the exchange. This is the case in the US, where social ties are more informal and implicit (Arrow, 1998), as well as in China's guanxi culture, where there is more of a sense of explicit obligation (Fei, 1992 [1949]; Hwang, 1987). US social ties are certainly based on family and neighborhood connections, but they also may work through acquaintances, work colleagues, school friendships, or even casual connections that seem to take on significance because of a feeling of similarity or identity. Even so, an important boundary in understanding how social networks work in the US is that network ties exist within a system of economic inequality expressed among other ways in extreme residential segregation, which determines where people go to school, where they worship, where they form friendships, and often where they work (Logan \& Molotch, 1987; Massey \& Denton, 1993). Such residential segregation is based especially on racial and ethnic divisions that are pervasive and strong in the US. The use of social ties in the labor market in the US, therefore, reinforces and perpetuates racial inequality (DiTomaso, 2013; Schmutte, 2016a).

Within China, guanxi relationships are more specific than general in Putnam's definition (2000) in that they are based on the accumulation of obligations within interpersonal relationships, often based on kin or kin-like connections (Bian, 1994; Bian, In Press; Bian \& Ang, 1997; Chang, 2011; Guthrie, 1998; Lin \& Bian, 1991; Lin, 2001a; Lo \& Otis, 2003). Using a definition by Jacobs (1979), Tsui and Farh (1997) define guanxi as 'the existence of direct particularistic ties between two or more individuals'. Bian (1994: 974) argues that the interpersonal relationships of guanxi can have three meanings: (a) a potential relationship between people who share a status group, (b) a direct connection between people who share mutual obligations, and (c) a reference to people with whom one has a strong connection. In explaining the nature of the relationship and its importance in Chinese culture, Bian (2006: 312) uses the following definition: '. . . guanxi (or kuan-his) refers to a dyadic, particular and sentimental tie that has potential of facilitating favour exchanges between the parties connected by the tie'.

Traditional guanxi relationships in China were hierarchical, based on the Confucian role relationships of emperor-subject, father-son, husband-wife, elderyounger brothers, and friend-friend (Chen et al., 2013; Tsui \& Farh, 1997: 60). Such relationships were intimate, long-term, characterized by trust, and thus, constituted strong ties, in Granovetter's terminology (1973, 1995). As China has 
been changing toward a more hybrid society that mixes both state and nonstate sectors with an emergent market economy, guanxi relationships have been changing as well, but they still retain the hierarchical, personal, and long-term character that is overlaid with a sense of moral obligation between those in the relationship (Lo \& Otis, 2003). Guanxi relationships define the interdependence and mutual obligations among the Chinese, which are thought to hold together Chinese society (Fei, 1992 [1949]; Hwang, 1987; King, 1985; Liang, 1986 [1949]; Walder, 1986; Yang, 1994, 2002). In a much stronger sense than in the US context, in China guanxi relationships create moral obligations, not just cultural expectations. Although guanxi relationships are mostly based on family and kin relationships, friendships can also generate guanxi relationships, but when they develop, they are thought of as pseudo-familial and expected to be long term (Lin, $2001 \mathrm{a}$; Lo \& Otis, 2003). Indeed, Burt and Opper (2017) find that while family ties are frequently present in entrepreneurial foundings that they do not form a majority of key ties, and that those entrepreneurs who draw from broader networks of close ties are more successful over the long run.

In both the US and China, such exchanges of favor are particularistic. That is, in both places they are intended to circumvent competition for jobs and other social resources in order to benefit those who have access to decision makers and thereby gain special privileges as a result. Although both types of relationships are particularistic, the connections are closer within China and more variable in the US (Son \& Lin, 2012). Relationships in the US have boundaries that cover a broader range of connections from which an individual might draw benefits than is the case in China. In the US social relationships are also less clear in terms of when and under what circumstances favors will be offered or collected (DiTomaso, 2013), whereas in China guanxi relationships have more clearly understood expectations of favor exchange.

In both the US and China, there has been growing research interest in how social connections affect life outcomes (Bian, 1997; Bian \& Huang, 2015; Blau, Ruan, \& Ardelt, 1991; Burt, 2000; Castilla, 2005; Chen \& Chen, 2004; Chen et al., 2013; Elliott, 1999; Fernandez, Castilla, \& Moore, 2000; Lin, 2001a; Luo, Huang, \& Wang, 2012; McGuire, 2000; Qi, 2013; Royster, 2003; Seidel, Polzer, \& Stewart, 2000; Smith-Lovin \& McPherson, 1993; Tsui \& Farh, 1997; Waldinger, 1997). In general, the research has found that networks improve outcomes in terms of access to resources for some more than others. There is unequal access to the most beneficial networks in both countries, that is, to those with access to valuable social resources and to those who can be effective in providing access to jobs that are protected from competition. In both the US and China access to social relationships have been an important mechanism for finding jobs or progressing in them, despite political systems in each country that in different ways supposedly limit the influence of such connections.

In some characterizations of social capital use in the US, there is a presumption that the primary benefit of social ties is access to information from broader social 
networks than one might have available otherwise (Burt, 1992; Granovetter, 1973). But access to social capital clearly provides more than information (Lin, 1982; Lin, 1999b), and information itself is not a neutral good. Its value depends on whether it is available to everyone or only to those who have an inside edge. In addition, social capital ties in the US involve the use of influence, where someone can be selected out of a group because an important social tie vouched for the individual. Social capital exchange in the US also involves direct opportunity, where someone with a job or hiring authority can actually offer a job (Coverdill, 1998). In China, despite the growing market-based sector, there is perhaps less leeway for social ties to actually offer positions (Hanser, 2002; Huang, 2008), but both information and influence are frequently exchanged in China. Research on the Chinese job market has found that one can use social ties to influence decision-makers in the state sector who are responsible for allocating jobs or promotions as well as in the nonstate sector where decisions may be made by entrepreneurs or their designated managers (Bian \& Huang, 2015; Burt \& Opper, 2017; Tian \& Lin, 2016; Zhao, 2013).

In summary, we argue in answer to our first question about how it is possible that in such different cultural and political systems social ties can have a strong influence on who gets jobs, that in both the US and China, social ties are used to avoid competition and to gain an inside edge from decision makers. Although the role of the market differs in the two countries, competition for access to jobs is high in both countries. The US has a well-established capitalist, market economy, while China continues to have a large state sector, albeit with an emerging market of entrepreneurial ventures, but in both countries, social influences affect who gets which jobs. In the US, the use of social capital has been brought to bear to avoid market competition and to circumvent anti-discrimination laws that are supposed to put everyone on an equal footing in the job search process. In China, the use of guanxi has been increasing as a way to gain access to job assignments or promotions, as a transition is underway that is contributing to the emergence of a market-based sector. That is, these social processes affect labor market outcomes for job seekers as the market in the US is circumvented by decision makers, whereas in China, these social processes affect labor market outcomes for job seekers as China moves toward more market influences in the job search process.

\section{The Structure of Labor Markets in the US and China}

This overview leads us to our second question: What are the mechanisms or processes by which people find jobs in the US and China, and how are people able to access these mechanisms or processes in the context of constraining social structures and legal environments? In the US, although there is widespread recognition of the importance of networking and getting to know people who might be helpful in one's career (Baker, 1994, 2000; Bayer, Ross, \& Topa, 2008; Hellerstein, McInerney, \& Neumark, 2011; Schmutte, 2016b), there is still an 
assumption that the job market largely functions in terms of competition among individuals who are evaluated based on their individual merit (Mincer, 1974). Most research on the job market focuses on the 'market' aspects of the job search, underlining the assumption that there is competition for jobs and that those chosen for most jobs are selected on the basis, for example, of education and experience (Mincer, 1974). Such research has often been guided by analyses of what is called human capital, or the investments that people make in themselves to improve their skills and abilities (Becker, 1964; Ben-Porath, 1967; Mincer, 1997). With the assumption that job market outcomes reflect inputs in the investments in education and experience, a great deal of the research on labor market inequality within the US context has been on determining the differences in the education and experience of various categorical groups (e.g., women and racial minorities), whether the education and experience that they have pays off in the same way or to the same extent, and whether the access to and quality of education and experience are equally available to different social groups (Aigner \& Cain, 1977; Becker, 1985; Bendrick et al., 1991; Bielby \& Baron, 1986; Bridges \& Nelson, 1989; Browne \& Misra, 2003; Campbell, 1988; Castilla, 2008; Cotton, 1988; Darity \& Nembhard, 2000; Fairlie \& Kletzer, 1998; Holzer, 1994; Massey, 2007; Reskin, 2000). Although this research often highlights the importance of information available through social connections and the relative importance of formal versus informal job search channels, the role of social networks in the job search process has been thought more as a side issue than as the foundation of job market processes within the US. In other words, social connections are evaluated in terms of whether they make the labor market more efficient or whether they facilitate better matches between employees and jobs, but social connections are not seen as determinative as much as supplementary (Burks et al., 2015; Galenianos, 2014).

That is, the role of social ties in the job search process in the US is acknowledged within labor market research, but such ties are often characterized as a supplement to education and experience and primarily as a means for obtaining information about jobs. The labor market disadvantages experienced by women and nonwhites are often attributed to their lack of social ties or to their need for 'mentors' who can give them advice about the job market (de Janasz et al., 2003; Fagenson, 1989; Falcon \& Melendez, 2001; Ibarra, 1992, 1995; Lunding, Clements, \& Perkins, 1979; McGuire, 2000; Thomas, 2001). In this research, there has also been an assumption that opportunities are most likely to emerge for those who can tap into weak ties, i.e., relationships that link to people who have non-redundant information not available in one's local environment (Burt, 2000, 1997, 2001; Granovetter, 1973). Because women and nonwhites are thought not to be able to gain broader access to labor market information, some have argued that women and nonwhites, for example, need to 'borrow' social capital from white men (Burt, 1998). McDonald et al. (2009), though, find that women and blacks (but not Hispanics) have as much social capital ties as do white men, but that the social capital white men have pays off in more job leads than it does for women or blacks. 
Despite the continued focus in labor market research on education and experience, in recent analyses, some have argued that the use of referrals or networks in job search has been increasing in the US and that the use of referrals improves the match between people and jobs (Bayer, Ross, \& Topa, 2008; Brown, Setren, \& Topa, 2016; Hellerstein, McInerney, \& Neumark, 2011; Schmutte, 2016a, 2016b). At the same time, such analyses have shown that the extensive use of referrals in the job search process also increases inequality, especially by race and ethnicity (Darity, Dietrich, \& Guilkey, 2001; Schmutte, 2016a). In contrast to what appears to be happening in practice, the notion of a labor market in which people compete for jobs based on merit is embedded in US laws against discrimination at both the federal and state levels, and such laws are intended to preclude discrimination based on race, color, religion, sex, and national origin. Typical analyses of discrimination in the labor market use multiple regression analyses to predict earnings from education, experience, and effort measures such as hours or weeks worked. The unexplained variance in such models is often interpreted as an indicator of discrimination, thus, suggesting that anything not based on merit defined in these models as education, experience, and effort - is prohibited by law. Although there are sometimes discussions about the quality of education as an omission from the models that might reduce the amount of unexplained variance, there has been only recently fuller consideration of networks as a similarly omitted and consequential factor (Bayer et al., 2008; Cingano \& Rosolia, 2012; Hellerstein et al., 2011; Schmutte, 2016b). Not giving greater attention to the role of networks or social capital in labor market analyses perhaps reflects that such connections are considered illegitimate, despite the growing literature with advice on how to search out and extend social networks (Baker, 2000; Granovetter, 1995; Lin, 1999b).

Because of the Confucian influence on Chinese culture, in pre-revolutionary China, the use of social connections in the form of guanxi was taken for granted as the primary means by which people got jobs. It was a system that was well understood by the population, despite the contribution to substantial inequality (Fried, 1953). The revolutionary goals introduced by the Communist revolution in 1949 sought to limit or end the influence of social ties in the distribution of opportunities and benefits and to invest state-owned agencies and their leaders (called cadres) with the decision-making authority to place people within work units and jobs (Vogel, 1965). Because the revolution also created state-owned enterprises and created collective farms, the control of cadres over labor force assignments was substantial (Whyte \& Parish, 1984). Associated with the control of the Party cadre members over the labor force was the long-standing system of household registration in China, called the hukou system, which restricted most people to the locations where they were born (Wu \& Treiman, 2004). Although the use of guanxi for exchanging favors prevailed in China after the 1949 revolution (Gold, 1985; Walder, 1986), the overwhelming majority of jobs were state-assigned by the late-1970s (Bian, 1994). Following Mao's death and in the wake of globalization pressures, however, reforms were introduced in 1978 which contributed to greater 
opportunity for the emergence of a market economy, including a private sector labor market. With the growing proportion of jobs in the private rather than state sector enterprises, there has been an erosion to some extent of the control of cadres over labor force assignments, which has allowed much greater movement from rural areas to the cities, as well as for a greater role again for the use of guanxi ties in the effort to obtain favorable placements or access to better jobs (Bian \& Huang, 2015; Bian, Huang, \& Zhang, 2015; Chen \& Volker, 2016; Tian \& Lin, 2016). The growth in the use of guanxi ties in the job search process affects both the state and the non-state sectors. Guanxi ties have also played a role in the development of entrepreneurial ventures, especially in the early days (Burt \& Opper, 2017).

One of the key academic questions with regard to China that has arisen since the 1978 reforms has been the extent to which cadre members still maintain their advantages in the economy because of their responsibility to assign people to work units and jobs or whether the growth of market forces, including a newly developed private sector labor market, has contributed to a new basis for stratification in post-revolutionary China (Bian, 1997, 2002; Bian \& Huang, 2015; Nee, 1989, 1991, 1996; Nee \& Matthews, 1996; Walder, 1996, 2003; Zhou et al., 2003). Nee (1989, 1991, 1996) introduced what he called the market transition theory to argue that the role of cadres in determining access to jobs weakened after the 1978 reforms, leading to more market influences on labor market dynamics. Market transition theory has been contrasted with what has otherwise been called state redistribution theory to explain the transition from communism or socialism to more market-oriented societies not only in the labor market, but also in terms of the emergence of entrepreneurs, the role of firms, and the relationships between both workers and firms with the state in post-socialist contexts (Bian \& Huang, 2015; Bian \& Logan, 1996; Bian, Shu, \& Logan, 2001; Burt \& Burzynska, 2017; Lin, 1995, 2011; Nee \& Cao, 1999; Nee \& Opper, 2010; Parish \& Michelson, 1996). In contrast to market transition theory, other scholars, however, have argued for a theory of power persistence (Bian \& Logan, 1996) and a theory of coevolution (Zhou, 2000), suggesting that despite the encouragement of markets that political cadres managed to retain their role in the allocation of resources. Further, Rona-Tas (1994), in an analysis of the transitions taking place in Eastern Europe, argued for a power conversion thesis that suggested that political cadres are able to retain their access to political power because of their ability in the context of market transitions to use their positions to gain control of state resources. His analysis has been picked up and applied to the Chinese context as well (Bian et al., 2015; Nee \& Opper, 2010; Walder, 2003; Zhou, 2000).

In market transition theory, researchers have argued that there has been a gradual transition toward the emergence of markets, including within the job search process. In this argument, the growth of entrepreneurial firms and the introduction of foreign capital into the country have both contributed to a loosening of state control over labor market decisions. In contrast, those analyses that have concluded that there has been a persistence of the role of the state in 
redistribution, including in the job search process, have concentrated on the extent to which cadres are still central to job assignments and still control the ability to change or improve jobs for job seekers. In such analyses of the Chinese labor market, attention has been given to whether education or social ties are more important, as well as to what the mechanisms might be that link education and social ties to labor market outcomes (Bian \& Huang, 2015; Bian et al., 2015). Those who have argued that education has become a more important explanatory variable in both job attainment and earnings than it had been in the prior period believe that these findings support market transition theory, whereas those who have found that social ties still play a large role in how people get jobs, including ties to state cadres, argue that there has been a persistence of the power dynamics within the state sector, despite the emergence of market reforms. A recent analysis by Bian and Huang (2015) found that private employers were as relationally embedded and constrained to provide jobs as favors to close others as were state cadres, although rules regarding merit screening were more prevalent in larger firms.

Bian and Huang (2015) also found that guanxi connections were less likely to channel jobs to workplaces with more merit screening, and yet, the use of guanxi in the job search process has been increasing overall in China. In an analysis of a series of surveys that span from 1978 to 2009, Bian (In Press) found that the use of guanxi in job searches increased from $46 \%$ in 1978 to $80 \%$ in 2009 , suggesting a dramatic increase in the use of guanxi in China, as the economy has transitioned from a command to a hybrid economy with a growing market-based sector. Even in a study of eight major urban areas, where it has been acknowledged that market processes are more advanced, $61 \%$ of over 5000 respondents in the state, non-state, and hybrid sectors were found to have used guanxi to find jobs (Bian \& Huang, 2015: 972). Further, even in the state sector, where cadres are supposed to have more influence to overcome class or status effects, guanxi has been found to be the means of contact, either directly or indirectly with state cadres (Bian \& Huang, 2015). That is, when state cadres have continued to have decision-making authority in the job market, there is evidence that their decisions are influenced by the social ties of job seekers.

Since the role of guanxi has risen with the emergence of a private sector labor market, it is clear that guanxi has influence on access to private sector jobs as well as to those in the state sector. In other words, as the emergence of private sector markets have opened up new opportunities for Chinese job seekers and for entrepreneurs, the use of guanxi in job seeking dynamics have reinforced the tendencies toward inequality that were the targets of the revolution itself. As more empirical work has accumulated, it seems clear that not only has guanxi continued to influence job seeking in China since the economic transformation, but that its use has increased substantially.

Thus, empirical work is beginning to provide more evidence about the continued use of guanxi in the job search process in China (Bian et al., 2015; Obukhova, 
2012; Son \& Lin, 2012; Tian \& Lin, 2016; Zhao, 2013), contributing to growing agreement on some aspects of the empirical findings, even if not on the interpretations. Most current research argues that China has become a hybrid system that mixes state-controlled enterprises with a large private sector that is more subject to market forces (Lin, 2011; Nee, 1992). While the research has found that political leaders are not as relevant to job access in urban areas, there is agreement that they still play a large role in rural areas, especially in those areas where there has been the growth of 'local state corporatism' in which local elites control township or village industries (Lin, 1995; Oi, 1999). In general, where firms are more dependent on state clientelism, political cadres still maintain a substantial influence on economic decisions. Further, even with the growth of market forces, in countries like China, cadre members have been best positioned to take advantage of the new market opportunities, both in entrepreneurship and in becoming indispensable in making available key business resources, such as licenses and the efficient processing of transactions (Bian, 2002; Nee \& Opper, 2010; Walder, 2003), thus enabling their continued influence on job market decisions in both the state and non-state sectors. In a Chinese context, some have discussed this as 'generalized particularism' (Lo \& Otis, 2003; Qi, 2013), i.e., the emergence of close relationships of favor exchanges similar to the traditional meaning of guanxi but ones that are not necessarily based on kinship.

In the US, research evidence suggests that instead of facing the competition of the job market, those who can do so, rely on social contacts, i.e., on the information, influence, or opportunities that are provided by friends and acquaintances, sometimes as payback for favors and good deeds in generalized social relationships in a given community or group and sometimes as the beneficiaries of a close social network (Alexander et al., 2014; DiTomaso, 2013; Granovetter, 1995; Royster, 2003). Most of the time these efforts are informal and are not based on quid pro quo. Instead, they are generalized exchanges, that is, favors exchanged within a set of social relationships that are not specific to time or person, but instead, are exchanged, in general, among people who feel a sense of identity or solidarity with each other (Bourdieu, 1986; Coleman, 1988; Putnam, 2000). Such exchanges take place because the people involved believe at some level that the community as a whole will be better off if people help each other. Thus, in many cases, people get help from those who are part of an extended network, but who are not necessarily close family or friends.

In the US context, social groups can have multiple points of connection that are nested in and through other groups and that can be arrayed in a dense or loose configuration. The boundaries of such groups, as is characteristic of the more individualist culture of the US, may be more or less permeable, and access to such groups may be relatively easy or difficult to obtain (Triandis, 1995). Further, most individuals are members of many different groups, based on residence, school, religion, work, ethnicity, race, national origin, hobbies, interests, life stage, and many other such aspects of their lives. Toward any given group, however, an 
individual's link may be tight or loose, or strong or weak as Granovetter defines it (1973).

Generalized reciprocity or generalized social capital in the US and generalized particularism in China are not the same thing as weak ties, because such generalized social relationships are conceptualized as taking place within a community, whereas weak ties are often thought of as bridging different communities. In the US, such generalized relationships can be rather diffuse in terms of how the social groups are defined within which there is a sense of personal obligation to help, whereas in post-revolutionary China, generalized relationships are still rather specific because they are kin-like even when not based on kin.

In a labor market context, the ties to social groups are useful to the extent that they help protect individuals from competition in the job market and when they can provide resources to help if the market shifts in a direction that adversely affects people. Such advantages provided by social group memberships are called 'social resources' (Lin, 1982), and these may include access to resources that are both material and nonmaterial or tangible and intangible (McPherson, SmithLovin, \& Cook, 2001; Smith, Smith-Lovin, \& McPherson, 2014). Lin (1999a) calls these distinctions instrumental and expressive outcomes. The material or tangible resources are also called economic or 'financial capital', which includes the money resources acquired by an individual or resources that are available from social connections, for example, monetary gifts or inheritances, loans (with interest often below the going market rate and sometimes with no interest), and also favors that defer costs (such as being able to live at home for free or to receive free babysitting). Nonmaterial or intangible social resources are also part of 'social or cultural capital'. Adler and Kwon (2002) define social capital in terms of information, influence, and solidarity, but it seems clear that one of the key resources available from social networks is the ability to actually offer a job or to provide opportunities that concretely lead to specific benefits (Alexander et al., 2014; DiTomaso, 2013; Hewlett, 2013; Royster, 2003).

The extent to which social connections or networks - or what Granovetter calls 'networks of social relationships' (1995) - determine access to jobs has been controversial within the US labor market literature, in part, because of the assumptions that jobs are found within a market context in which most can freely compete, even though some have greater preparation and skill development than others. In a recent analysis of job histories of whites in three US states, however, DiTomaso (2013) found that the majority of jobs (almost 70\%) obtained over a lifetime by the interviewees in her sample were found with the help of social capital, including information not available to others, the use of influence from those who could make a difference in terms of who gets hired, or by providing opportunity, meaning offering a job (Adler \& Kwon, 2002). DiTomaso collected data on all jobs held by her interviewees from high school to the time of the interview and asked about the circumstances under which each job was obtained. By probing in those circumstances where specific social capital was not mentioned by the 
interviewees, she was able to expand the estimates about the prevalence of social capital use in job search from previous analyses. Despite the additional probing in face-to-face interviews, DiTomaso's estimates are not so different from Granovetter's (1995), especially given the differences in methodology. Granovetter (1995) found an average of 56 percent of his sample found jobs through personal contacts, with the proportions rising with age, but his sample included only professional, technical, and managerial employees, and only jobs that had been sought in the previous five years before the study. Further, he excluded those cases where there were multiple means used to find a job, whereas DiTomaso included all those cases where personal contacts were mentioned. Granovetter (1995) also interviewed only about a third of his interviewees, while obtaining information from the rest through a survey, so he was not able to probe for connections to the extent that DiTomaso had done. DiTomaso's findings are reinforced by the study of private sector employers by Stainback and Tomaskovic-Devey (2012) in which they found that after a slight decline in the degree of job segregation in which white men had been favored, that white men have actually maintained or increased their access to the best jobs in the fifty years since the passage of the US Civil Rights Act.

In both the US and China, although merit is supposed to govern the access to jobs and opportunities, social networks and social connections play a major role in the outcomes of who gets what, especially with regard to jobs. Increasingly, research has found similar effects of social networks on job search and outcomes across countries, although the nature of social ties may differ along with how readily they offer assistance (Cingano \& Rosolia, 2012; DeGraaf \& Flap, 1998; Gerber \& Mayorova, 2010; Huo, Huang, \& Napier, 2002; Korpi, 2001; Ma, Huang, \& Shenkar, 2011; Obukhova, 2012; Sharone, 2014; Yakubovic, 2005). Thus, despite institutional, normative, and sometimes legal prescriptions to ostensibly limit the role of favoritism or advantage across countries, social ties in many contexts provide some with greater opportunity than others, and hence, shape important life outcomes to some degree. And, despite the wide differences in social systems and culture, social ties affect access to jobs in the US even with laws against discrimination and in China even though revolutionary principles were expected to reduce class influences. As Blau et al. (1991: 1037) suggest, perhaps 'particularism governs personal relations regardless of cultural, political, or economic differences'. In both the US and China, particularism influences outcomes with regard to labor markets, including job assignments and promotions, income, and other nonmonetary rewards, as well as perquisites in the US or social services such as housing in China.

In summary, in both countries there is widespread use of social networks by job seekers as a means to gain access to valuable social resources that make a difference in life outcomes for themselves and their families. While the structure of labor markets in China and the US are very different and while both have legal systems that are intended to limit the use of particularism in the job search process, both have become, in actuality, hybrid systems, in which competition for 
jobs is overlaid with active use of social connections for job seekers to try to find an inside edge to get good jobs. While the US has a fully developed market economy, the extensive use of social connections by a majority of job seekers protect some from market competition by providing them with information other people do not have, the benefit of influence on which others cannot draw, and sometimes direct opportunity for a job or a good job assignment that is not available to others. Although China represents a mix of state and non-state sectors since the 1978 reforms and has been characterized as a hybrid system, there is evidence that guanxi favors come into play in a substantial proportion of job searches across sectors. There are differences in the way that these processes are experienced in the US and China. The differences reflect the specifics of the social, political, economic, and cultural systems within each country. Yet, in both the US and China, job seekers endeavor to gain an edge in a competitive environment or to avoid having to face competition altogether by drawing on friends, acquaintances, and others with whom relationships are formed that are overlaid with a sense of mutual obligations.

In the US social ties are more informal, sometimes even casual and invisible, and there are many avenues through which to pursue connections that might be valuable in a job search. In China, social ties are more visible and oftentimes deliberate, are kin-based or kin-like, and there are many publicly recognized activities expected that lead to social connections making a difference, even a final difference in critical decisions. Social connections in the US may be close and long-standing, through family and neighborhood connections, but they also may be more distant and fleeting. In China the exchange of favors in a guanxi relationship takes place among those who have long-standing connections, overlaid with moral obligations to help each other, and are either based on kin relationships, or are fostered such that they are similar to kin relationships (Lo \& Otis, 2003). In the US, there are major boundaries around who will help whom that are often defined by race and ethnic relations and sometimes gender, while in China there are major boundaries around party membership and political affiliations, the urban-rural divide, and state versus non-state sectors. Relationships in the US are broad and cross many boundaries, but tend to be racially segregated. In China, relationships are close-knit and family- or community-based, and when relationships develop outside of these boundaries, there is an effort to recreate a sense of moral obligation that are like traditional guanxi relationships.

Despite laws in the US that are supposed to guide competition in labor market relations and despite the influence of state cadres still evident in the hybrid Chinese system, in both countries, there is extensive evidence that social connections in the job market affect the practices that actually take place. In the US, social capital is more generalized in that social identity defines a sense of obligation among people who think of themselves as similar to each other. In China, guanxi increasingly is taking the form of generalized particularism that is nonetheless more specific than is the case in the US in that favors are exchanged among specific individuals who 
have built up a relationship that is kin-like among parties who understand the need to exchange favors within that relationship.

Bian (2002) argues that social connections in China are more likely to be based on strong ties than might be the case in the US. In this regard, he notes (Bian, 2002: 108):

All of these studies show that guanxi contacts are predominantly relatives and friends of high intimacy to guanxi users, but when they are acquaintances or distant friends, connections are made through intermediaries to whom both guanxi users and contacts are strongly tied. . . . Weak ties in western countries are used to learn information about job openings, whereas strong ties in China are meant to secure influence from authorities that was more difficult to obtain.

As we have already noted, however, in the US, social connections provide access not only to information, but also to the use of influence, and directly to opportunity, whether the ties are weak or strong. On average in the US, ties are probably weaker, but where available and relevant, US job seekers use strong ties as well.

While the US and China represent distinct political and cultural systems, in both cases, particularism seems to dominate in the job search process, even when law and culture have attempted to enforce universalism. The US and China represent hybrid systems that are emerging from opposite directions: In China, the political revolution attempted to reduce the influence of guanxi in the allocation of jobs and other social resources, but in the movement toward a market-based system, guanxi has re-emerged and has been increasing in prevalence. In the US the use of social capital connections has been focused on avoiding market competition. Thus, social connections have emerged as China has progressed toward a market economy, while they have emerged in the US, in ways that undermine the influence of markets in the job search process. In both cases, these countries have arrived at hybrid systems (in China toward markets and in the US away from markets) in which social connections play a major role in how people get jobs.

\section{Theoretical Implications}

As our overview has shown, despite distinct political, social, economic, and cultural systems, in both the US and China, job seekers extensively use social connections in the job search process and do so through similar mechanisms. That a majority of people seeking jobs in both countries appear to obtain them over their lifetimes with the help of social connections that protect them from competition raises a number of theoretical questions. How can we better understand the ways that 'generalized particularism' seems to shape the labor markets in the US and China? We endeavor in this section to suggest some principles that seem to guide the structure of labor markets in both countries. Both in a capitalist country with a well-developed job market and in a communist country like China, where the job market is still emergent and political elites continue to have an outsized role in 
determining the allocation of social resources, social connections play a prominent role in the job search process. Despite the iconic differences between the US and China, in values, cognition, self-construal, communication patterns, religion, and politics, the influence of social networks in the allocation of valuable social resources can dominate the access to jobs, as well as to promotions, social benefits, income, and other positive life outcomes. In both the US and China, most people from dominant groups find most of their jobs with the help of social connections over their lifetimes, including jobs in the public sector, the private sector, or the hybrid sector.

In this sense, the talk about labor 'markets' seems to be a misnomer. What we call 'markets' seems to be less open than is often believed, and there appear to be many avenues for gaining unearned access to avoid market competition by using social connections. Importantly, the insiders and outsiders in this dynamic are not random, but rather are as Bourdieu (1986: 248) defines it, based on 'a durable network of more or less institutionalized relationships of mutual acquaintance or recognition'. In the US, the institutional bases for social inequality are determined by categorical differences such as race/ethnicity, class, religion, gender, and other markers of 'differences that make a difference' (DiTomaso, Post, \& Parks-Yancy, 2007). In China social divisions, such as whether one lives in an urban or rural region, works for a state or non-state sector, for a large or a small firm, or for a domestic or foreign-owned firm, also define life chances. In systems of inequality, especially where jobs play such an important role in terms of life outcomes, access to good jobs are characterized by a process of opportunity hoarding, that is, reserving job opportunities for family and friends or acquaintances (Tilly, 1998), that benefits those who are mutually recognized (Bourdieu, 1986). In a long term system of inequality, social distinctions and the exchange of favors lead to outcomes that are often legitimized as the product of merit JJackman, 1994; Mills, 1997; Sidanius \& Pratto, 1999). It is hard to think of the use of networks or social connections as exceptions to the rule, though, when the majority of jobs are found by using such connections. Instead, it suggests that the use of social connections is not the exception, but rather is the rule of how jobs are found. In the individualist culture of the US, job seekers often believe that they determine their own fate, and indeed, DiTomaso (2013) found that her US respondents believed that their life outcomes were the result of their own hard work and motivation. They disavowed that anyone had helped them in their lives, despite the fact that the majority revealed in their interviews that most of their jobs were obtained with the help of others in their social networks. In the collectivist culture of China, where longterm, family-like relationships are overlaid with mutual and moral obligations to exchange favors, it is likely that job seekers may think that their use of social connections fulfills a moral purpose, rather than seeing their use as a form of particularism.

In both the US and China, the use of social connections to obtain valued social resources is dominant in the systems of stratification, and yet in both countries, 
there is an ideology of merit about who succeeds. Social connections are treated in both theory and practice as an add on to capability and preparation, even when it is clear that developing capability and preparing oneself require access to social resources, to the help of family and friends, and to the opportunity to gain favor that is not available to others. In the US, those with class and racial advantages are more likely to live in resource rich social environments, to have the resources to invest in their human capital, and to get many chances to achieve and excel, despite any gaps in motivation or talent. In China, political cadres have both greater access to education and greater opportunity to expropriate state resources for entrepreneurial ventures for themselves or for close social connections, and those in non-state sectors or in hybrid sectors are just as likely to take advantage of the opportunities available primarily through social connections. In both environments, access to advantages seems to be more consequential for life outcomes than disadvantage (DiTomaso, 2015).

Despite what we have presented about the similarities in the labor market processes in the US and China, we acknowledge, of course, that these processes are embedded within very different cultural, political, social, legal, and economic systems. Even with such iconic differences, the fact that in both countries particularism plays a major role in the allocation of important social resources raises questions that we have tried to address within this article. We have tried to describe for both countries how such systems function and the mechanisms or processes that enable people in each country to tap into generalized particularism and to avoid the constraints of both social structure and the legal environments. We want to go a step further, however, in outlining some suggestions about when particularism is more likely in the job search process, not only in the US and China, but more generally.

We suggest that particularism emerges and becomes prevalent, even in the context of legal and cultural constraints that are intended to enforce universalism (Bian, In Press), when uncertainty in the economic environment is great, when competition for jobs is strong, and when the outcomes in terms of life chances are especially consequential. In both the US and China, job seekers draw on homophily, opportunity hoarding, and social closure through the use of networks (Smith-Lovin \& McPherson, 1993; Tilly, 1998; Weber, 1968), whether social capital in the US or guanxi ties in China. But, in each country, these processes exist within embedded laws, customs, and the structure of opportunity available at a given time. Particularism works differently in the US and China, and its use depends on the extent of access to those with resources and power. Further, the type of processes that develop are shaped as well by the types of boundaries that are being linked or bridged. In the US, race and ethnicity are especially important boundaries. In China, boundaries between urban and rural dwellers, between those in government positions versus those in market-based positions, those in large firms and those in small, and those in Chinese companies versus those working in foreign-owned firms all have an effect on the job search process. 
Thus, to understand how social connections affect the job search process, we need to take into consideration not only the relationships among people, but also the differences among firms and the competitive environments that they face. Both the structures in place for firms to oversee the job search process and the cultural influences that encourage or enable the use of social ties in decisionmaking affect how prevalent social connections are in any given labor market. These may differ across societies. The US and China are simply illustrative of these processes, which otherwise seem to be much more general (Bayer, Ross, \& Topa, 2008; Cingano \& Rosolia, 2012; Hellerstein, McInerney, \& Neumark, 2011; Rona-Tas, 1994; Sharone, 2014). We argue that the extent to which social connections matter for jobs in any given society depends on how the societal system is constrained by both formal and informal institutionalizations. Formal institutionalization refers to how strong and practically effective the laws, rules, and regulations are in a given labor market. Especially important in this regard is whether there are formal personnel systems that guide the review and selection of candidates to hire. Also important is how much competition the firm faces in the economy, i.e., whether the firm's survival depends on efficiency concerns. Informal institutionalization refers to how cultural values, norms, and repertories effectively orient the agents of a given labor market to behave within the constraints of formal institutionalization. When the social relationships among groups within the society exist within a context of inequality and competition for scarce resources, dominant groups may be better able to access social connections and gain an edge in the job market. We argue that formal institutionalization can be strong and practical or weak and impractical, while informal institutionalization varies between the cultural systems of generalized particularism and primordial particularism (Lo \& Otis, 2003). Generalized particularism is a system of social relationships that function to reproduce existing inequality through the exchange of favors among those in advantaged positions. Such exchanges strengthen community but only for those who are members of the ingroup. While the relationships may be specific or general, there is a sense of moral obligation to ingroup members, especially among those with access to advantages. Primordial particularism is based more on family and kin relationships that are likely to be more specific in terms of who has obligations to whom. It also functions primarily through ingroup favoritism.

We outline our conceptualization of these relationships in Table 1 in a two by two typology that represents four types of job sectors. In any given society, we expect that most jobs could be assigned to one of the four sectors in the typology. Given our analysis of the job search process in China and the US, we can describe where various types of jobs in each country might be located within each of these sectors. The same could be done with jobs in other countries as well, depending on the formal and informal institutionalization within those countries. Within our conceptualization of formal institutionalization, we differentiate larger firms and jobs that require more education or skill with more developed personnel systems from smaller firms, in more competitive environments, with lower skilled 
Table 1. A theoretical framework for how social connections matter for access to jobs

\begin{tabular}{|c|c|c|}
\hline \multirow[b]{2}{*}{$\begin{array}{l}\text { Formal } \\
\quad \text { Institutionalization } \\
\quad \text { (organizational } \\
\text { structure) }\end{array}$} & \multicolumn{2}{|c|}{ Informal Institutionalization (cultural relations) } \\
\hline & Generalized Particularism & Primordial Particularism \\
\hline \multirow[t]{6}{*}{$\begin{array}{l}\text { Strong, largely } \\
\text { practical, with } \\
\text { dedicated } \\
\text { personnel } \\
\text { systems }\end{array}$} & $\begin{array}{l}\text { Connections exercised within } \\
\text { formal systems of personnel } \\
\text { ostensibly organized as } \\
\text { merit-based selection }\end{array}$ & $\begin{array}{l}\text { Connections exercised within } \\
\text { formal systems of personnel } \\
\text { ostensibly organized as } \\
\text { merit-based, but engagement of } \\
\text { key decision-makers who can } \\
\text { intervene on behalf of applicants } \\
\text { with relational ties }\end{array}$ \\
\hline & Large corporations & Large workplaces \\
\hline & Professional \& managerial jobs & Professional \& managerial jobs \\
\hline & Skilled labor markets & Skilled labor markets \\
\hline & $\begin{array}{l}\text { Hiring procedurally documented } \\
\text { but flexible }\end{array}$ & $\begin{array}{l}\text { Hiring strongly influenced by } \\
\text { Number I Man }\end{array}$ \\
\hline & $\begin{array}{l}\text { A lot for the US, but rising in } \\
\text { China }\end{array}$ & $\begin{array}{l}\text { A lot for China in both state and } \\
\text { non-state sectors, and somewhat } \\
\text { for the US }\end{array}$ \\
\hline \multirow[t]{7}{*}{$\begin{array}{l}\text { Weak, largely } \\
\text { impractical, } \\
\text { with more } \\
\text { idiosyncratic } \\
\text { personnel } \\
\text { systems }\end{array}$} & $\begin{array}{l}\text { Connections exercised through } \\
\text { more informal processes in } \\
\text { which personal ties influence } \\
\text { decision-making but in a } \\
\text { competitive environment with } \\
\text { productivity goals, leading to } \\
\text { selection of both competent and } \\
\text { marginally competent } \\
\text { candidates }\end{array}$ & $\begin{array}{l}\text { Connections exercised through } \\
\text { more informal processes in } \\
\text { which 'the boss' is heavily } \\
\text { embedded in networks of social } \\
\text { relations; social connections } \\
\text { more important than merit in } \\
\text { hiring decisions }\end{array}$ \\
\hline & Small workplaces & Small workplaces \\
\hline & Short-lived entities & Short-lived entities \\
\hline & Unskilled labor markets & Unskilled labor markets \\
\hline & Owner-as-manager systems & Owner-as-manager systems \\
\hline & $\begin{array}{l}\text { Hiring powers with one or a small } \\
\text { number of active agents }\end{array}$ & $\begin{array}{l}\text { Hiring powers with 'the boss' } \\
\text { A lot for China, somewhat for the }\end{array}$ \\
\hline & $\begin{array}{l}\text { Quite a bit for both the US and } \\
\text { China }\end{array}$ & US \\
\hline
\end{tabular}

workers and more idiosyncratic personnel systems. Within our conceptualization of informal institutionalization, we differentiate intergroup relations in systems of long-term inequality where social obligations are embedded in broader social institutions from more interpersonal and familial relationships that exist within broader social relationships, but which function in terms of systems of power and status more locally.

These differences produce four sectors: (1) large firms, with high skilled jobs, with dedicated personnel systems, that ostensibly use merit-based screening; (2) large firms, with high skilled jobs, and dedicated personnel systems, but that are more entrepreneurial, where the founders still have a lot of influence on who gets 
hired; (3) smaller firms in more competitive environments, with less skilled jobs, where hiring managers need to be more concerned with competitive efficiency, but where social connections come into play; and (4) smaller firms in more competitive environments, with less skilled jobs, where the boss has a lot of influence in providing favors to family and friends.

Even where personnel systems are well developed and there are procedures for merit-based screening, social connections can still affect decisions about who gets hired. Getting a job in such a firm can be helped by someone with information about jobs being available passing along that information to family and friends (including before formal announcements are made), by letters of recommendation or putting in a good word with decision-makers who will then give more attention to specific applicants, and by decision-makers who may favor candidates who are connected to them or to people they know. These sorts of stories were familiar in the interviews conducted by DiTomaso (2013), and they are quite likely part of the process in the cities that were included in the study by Bian and Huang (2015), who found that a majority of jobs in eight urban areas were found with the help of guanxi connections. Formalization, thus, does not curtail the use of social connections, but it channels it.

Although we do not have direct evidence, it is likely that when personnel systems are more formal, that generalized particularism provides extra advantages to those among qualified applicants, rather than overrides qualifications in making selection choices. This is also likely to be the case, because jobs in larger firms with more educated or skilled labor forces require some qualification to meet the requirements of the jobs in such firms. There are more such jobs in advanced capitalist countries like the US, but these types of jobs are growing in China as the market-based sector expands. Further, foreign owned firms that are subsidiaries of large, multinational corporations are likely to have formal personnel systems in place that provide a framework for merit based hiring. This does not mean that merit is necessarily the basis for hiring decisions, but only that it is a screen through which applicants must go, and hence often the use of social connections must function within this framework.

Even with formalized systems, however, when leaders are especially powerful, they can have an outside influence on who is hired. Thus, social connections may play a larger role in hiring close family and friends in entrepreneurial firms. In the context of a system where the state controlled most hiring, market-based firms in China are more likely to be young, with the entrepreneurs still actively engaged. Further, the evidence has shown that social connections are still quite prevalent in China in the state-controlled sector as well, where those in positions of decisionmaking have fewer checks on their behavior and especially in areas of the country where the bases for doing business depend on favors from state cadres. Large firms with especially powerful leaders certainly exist within the US, but given the wellestablished principles of personnel management, even new and entrepreneurial firms in the US are likely to seek legitimacy by imitating the practices broadly 
used in the field. In both China and the US, thus, we anticipate that even in large firms, especially those with powerful leaders, relational ties may influence who gets hired and promoted. In both countries, social connections are especially likely to be accessed in entrepreneurial firms where the founders are still closely involved.

In more competitive environments, the exchange of information about the availability of jobs can be of special importance, because jobs may not be advertised or posted broadly. But smaller firms may also need to be more attentive to productivity concerns, and thus, while there may be a preference to hire family members or friends, the firm managers are not likely to put the survivability of the firm at risk by hiring people who are not capable of doing the job, perhaps with some minimal training. In such situations, though, personal connections may play a large role in hiring in both the US and China, even if decisions are made within the constraints of the need for efficiency. For less skilled jobs, efficiency concerns may not present strong barriers to employment because the workforce for unskilled jobs requires less in terms of preparation. Training on the job is often sufficient in such companies. Thus, in firms with a strong boss or leaders in highly competitive firms, we would expect the exchange of favors may take precedence over decisions based on merit. The use of connections in such firms is likely to be quite prevalent in both the US and China. Within the emerging market economy in China, though, we expect more firms where the 'boss' is still closely involved in hiring decisions, which is likely to make social connections in the hiring process even more prevalent. The same processes exist within the US for similar firms, but we expect somewhat more constraints in the US even for small firms with unskilled workers because of concerns with competitive pressures.

All of these processes may be strengthened when jobs are scarce and having a good job makes the difference between living a decent life versus living in poverty. When times are tough, personal connections take on a larger role, especially in systems where there are fewer constraints to helping family and friends. When times are flush and there are more jobs than people, personal connections may be less important for getting a job, thus opening up the job market to those in outgroups who otherwise might have been excluded. The existing system of inequality that gives advantages to some groups over others creates a structure to who is likely to get access to resources that are scarce and valuable, and places constraints through the formalization of personnel systems and the competitiveness of the environment. Under such circumstances, the consequential effects on life chances for those who can draw on social connections come into play in terms of the actual practices on the ground and in everyday life.

\section{GONGLUSION}

In both the US and China, jobs and social benefits are gained primarily through the use of social ties from family, friends, and acquaintances, despite major differences in culture, politics, and social stratification systems in the two countries. 
Although the majority of jobs are obtained with the help of social networks, academic research still holds on to the concept of a job 'market', with the assumption that there is far more competition based on qualifications and merit than appears to be the case in either country. Education and experience are often posed as factors that demonstrate merit rather than particularism, even though both are themselves the outcomes of access to social resources and to the ability to gain entry level positions that enable skill development.

Whether in a capitalist country or a communist one, people try to ensure outcomes that are favorable to themselves and to their families if they are able to do so by drawing on social connections that will enable them to avoid direct competition in job searches. Despite an ideology that life outcomes are the result of merit, in both the US and China life outcomes are usually guaranteed by the exchange of social favors for those who are well positioned to give and to receive. Based on a review of research on social networks in the US and China, we found that the use of social capital in the US is almost as pervasive as the use of guanxi in China in the job search process. Within the context of systems of inequality, especially under conditions of uncertainty and greater competition, people seek unequal opportunity or advantage, even if they espouse equal opportunity as a fair solution to existing inequality or claim to believe in merit. The biases that work to the advantage of dominant groups, whether defined by region (such as urban versus rural areas in China), class, race/ethnicity, religion, or gender function through the exchange of social resources that serve to reproduce inequality over time. In both the US and China, people generally know how things work, but those who are tasked with studying and describing social processes often create more of an ambiguous portrayal than the evidence seems to warrant.

\section{NOTES}

The authors are grateful to Management and Organization Review Editor-in-Chief Professor Arie Y. Lewin, Senior Editor Professor Jia Lin Xie, and two anonymous reviewers for their helpful comments on an earlier version of this paper.

\section{REFERENCES}

Adler, P. S., \& Kwon, S.-W. 2002. Social capital: Prospects for a new concept. Academy of Management Review, 27(1): 17-40.

Aigner, D. J., \& Cain, G. G. 1977. Statistical theories of discrimination in labor markets. Industrial and Labor Relations Revieze, 30(2): 175-87.

Alexander, K., Entwisle, D. R., \& Olson, L. 2014. The long shadow: Family background, disadvantaged urban youth, and the transition to adulthood. New York: Russell Sage Foundation.

Arrow, K. 1998. What has economics to say about racial discrimination. Journal of Economic Perspectives, 12(2): 91-100.

Baker, W. E. 1994. Networking smart: How to build relationships for personal and organizational success. New York: McGraw-Hill.

Baker, W. E. 2000. Achieving success through social capital: Tapping the hidden resources in your personal and business networks. San Francisco, CA: Jossey-Bass. 
Bayer, P., Ross, S. L., \& Topa, G. 2008. Place of work and place of residence: Informal hiring networks and labor market outcomes. Journal of Political Economy, 116(6): 1150-1196.

Becker, G. S. 1964. Human capital. New York: National Bureau of Economic Research.

Becker, G. S. 1985. Human capital, effort, and the sexual division of labor. Journal of Labor Economics, 3(1): S33-S59.

Ben-Porath, Y. 1967. The production of human capital and the life cycle of earnings. Journal of Political Economy, 75(4): 352-365. doi: 10.2307/1828596.

Bendrick, M.Jr., Jackson, C.W., Reinoso, V. A., \& Hodges, L. 1991. Discrimination against Latino job applicants: A controlled experiment. Human Resource Management, 30(4): 469-484.

Bian, Y. 1994. Guanxi and the allocation of urban jobs in China. The China Quarterly, 140(December): 971-999.

Bian, Y. 1997. Bringing strong ties back in: Indirect ties, network bridges, and job searches in China. American Sociological Revieze, 62(3): 366-385.

Bian, Y. 2002. Chinese social stratification and social mobility. Annual Revieze of Sociology, 28(August): 91-116.

Bian, Y. 2006. Guanxi. In J. Beckert \& M. Zafirovski (Eds.), International encyclopedia of economic sociology: 312-314. London, UK: Routledge.

Bian, Y. In press. The prevalence and the increasing significance of guanxi. The China Quarterly.

Bian, Y., \& Ang, S. 1997. Guanxi networks and job mobility in China and Singapore. Social Forces, 75(3): 981-1005.

Bian, Y., \& Huang, X. 2015. Beyond the strength of social ties: Job search networks and entry-level wage in urban China. American Behavioral Scientist, 59(1): 961-976.

Bian, Y., \& Huang, X. 2016. The guanxi influence on occupational attainment in urban China. Chinese Journal of Sociology, 1(3): 307-332.

Bian, Y., \& Logan, J. R. 1996. Market transition and the persistence of power: The changing stratification system in urban China. American Sociological Revieze, 61(5): 739-758.

Bian, Y., Huang, X., \& Zhang, L. 2015. Information and favoritism: The network effect on wage income in China. Social Networks, 40(January): 129-138.

Bian, Y., Shu, X., \& Logan, J. R. 2001. Communist party membership and regime dynamics in China. Social Forces, 79(3): 805-841.

Bielby, W. T., \& Baron, J. N. 1986. Men and women at work: Sex segregation and statistical discrimination. American Journal of Sociology, 91(4): 759-799.

Blau, P. M., Ruan, D., \& Ardelt, M. 1991. Interpersonal choice and networks in China. Social Forces, 69(4): 1037-1062.

Boisot, M., \& Child, J. 1996. From fiefs to clans and network capitalism: Explaining China's emerging economic order. Administrative Science Quarterly, 41(4): 600-628.

Bourdieu, P. 1986. The forms of capital. In J. Richardson (Ed.), Handbook of theory and research for the sociology of education: 241-258. New York: Greenwood.

Brewer, M. B., \& Chen, Y.-R. 2007. Where (who) are collectives in collectivism? Toward conceptual clarification of individualism and collectivism. Psychological Revieze, 114(1): 133-151.

Bridges, W. P., \& Nelson, R. L. 1989. Markets in hierarchies: Organizational and market influences on gender inequality in a state pay system. The American Journal of Sociology, 95(3): 616658.

Brown, M., Setren, E., \& Topa, G. 2016. Do informal referrals lead to better matches? Evidence from a firm's employee referral system. Journal of Labor Economics, 34(1): 161-209.

Browne, I., \& Misra, J. 2003. The intersection of gender and race in the labor market. Annual Revieze of Sociology, 29(August): 487-513.

Burks, S. V., Cowgill, B., Hoffman, M., \& Housman, M. 2015. The value of hiring through employee referrals. The Quarterly Journal of Economics, 130(2): 805-839.

Burt, R. S. 1992. Structural holes: The social structure of competition. Cambridge, MA: Harvard University Press.

Burt, R. S. 1997. The contingent value of social capital. Administrative Science Quarterly, 42(2): 339-365.

Burt, R. S. 1998. The gender of social capital. Rationality and Society, 10(1): 5-36.

Burt, R. S. 2000. The network structure of social capital. Research in Organizational Behavior, 22: $345-423$.

Burt, R. S. 2001. Structural holes versus network closure as social capital. In N. Lin, K. Cook, \& R. S. Burt (Eds.), Social capital: Theory and research: $31-56$. New York: Aldine De Gruyter. 
Burt, R. S., \& Burzynska, K. 2017. Chinese entrepreneurs, social networks, and guanxi. Management and Organization Revieze, 13(2): 221-260.

Burt, R. S., \& Opper, S. 2017. Early network events in the later success of Chinese entrepreneurs. Management and Organization Revieze, 13(3): 497-537.

Campbell, K. E. 1988. Gender differences in job-related networks. Work \& Occupations, 15(2): 179-200.

Cao, Y., \& Nee, V. G. 2000. Comment: Controversies and evidence in the market transition debate. American Journal of Sociology, 105(4): 1175-1 189.

Castilla, E. J. 2005. Social networks and employee performance in a call center. American Journal of Sociology, 110(5): 1243-1284.

Castilla, E. J. 2008. Gender, race, and meritocracy in organizational careers. American Journal of Sociology, 113(6):1479-1526.

Chang, K.-C. 2011. A path to understanding guanxi in China's transitional economy: Variations on network behavior. Sociological Theory, 29(4): 315-339.

Chen, C. G., \& Chen, X.-P. 2008. Negative externalities of close guanxi within organizations. Asia Pacific Journal of Management, 26(1): 37-53.

Chen, C. C., Chen, X.-P., \& Huang, S. 2013. Chinese guanxi: An integrative review and new directions for future research. Management and Organization Revieze, 9(1): 167-207.

Chen, X.-P., \& Chen, C. C. 2004. On the intricacies of the Chinese guanxi: A process model of guanxi development. Asia Pacific Journal of Management, 21(3): 305-324.

Chen, Y., \& Volker, B. 2016. Social capital and homophily both matter for labor market outcomesevidence from replication and extension. Social Networks, 45: 18-31.

Cingano, F., \& Rosolia, A. 2012. People I know: Job search and social networks. Journal of Labor Economics, 30(2): 291-332.

Coleman, J. S. 1988. Social capital in the creation of human capital. American Journal of Sociology, 94: 95-120.

Cook, K. S., Emerson, R. M., Gillmore, M. R., \& Yamagishi, T. 1983. The distribution of power in exchange networks: Theory and experimental results. American Journal of Sociology, 89(2): 275-305.

Cotton, J. 1988. Discrimination and favoritism in the US labor market: The cost to a wage earner of being female and black and the benefit of being male and white. The American Journal of Economics and Sociology, 47(1): 15-28.

Coverdill, J. E. 1998. Personal contacts and post-hire job outcomes: Theoretical and empirical notes on the significance of matching methods. Research in Social Stratification and Mobility, 16: 247-269.

Cuddy, A. J. C., Fiske, S. T., \& Glick, P. 2008. Warmth and competence as universal dimensions of social perception: The stereotype content model and the bias map. Advances in Experimental Social Psychology, 40: 61-137.

Darity, W.Jr., \& Gordon Nembhard, J. 2000. Racial and ethnic economic inequality: The international record. The American Economic Reviez, 90(2): 308-311.

Darity, W. Jr., Dietrich, J., \& Guilkey, D. K. 2001. Persistent advantage or disadvantage?: Evidence in support of the intergenerational drag hypothesis. American Journal of Economics and Sociology, 60(2): 435-470.

DeGraaf, N. D., \& Flap, H. D. 1998. With a little help from my friends: Social resources as an explanation of occupational status and income in West Germany, the Netherlands, and the United States. Social Forces, 67(2): 452-472.

de Janasz, S. C., Sullivan, S. E., Whiting, V., \& Biech, E. 2003. Mentor networks and career success: Lessons for turbulent times. The Academy of Management Executive, 17(4): 78-93.

DiTomaso, N. 2013. The American non-dilemma: Racial inequality zithout racism. New York: Russell Sage Foundation.

DiTomaso, N. 2015. Racism and discrimination versus advantage and favoritism: Bias for versus bias against. Research in Organizational Behavior, 35: 57-77.

DiTomaso, N., Post, C., \& Parks-Yancy, R. 2007. Workforce diversity and inequality: Power, status, and numbers. Annual Review of Sociology, 33(1): 473-501. doi:10.1146/annurev.soc. 33.040406.131805.

Elliott, J. R. 1999. Social isolation and labor market insulation: Networks and neighborhood effects on less-educated urban workers. The Sociological Quarterly, 40(2): 199-216.

Fagenson, E. A. 1989. The mentor advantage: Perceived career/job experiences of proteges versus non-proteges. Journal of Organizational Behavior, 10(4): 309-320. 
Fairlie, R. W., \& Kletzer, L. G. 1998. Jobs lost, jobs regained: An analysis of black/white differences in job displacement in the 1980s. Industrial Relations, 37(4): 460-477.

Falcon, L. M., \& Melendez, E. 2001. Racial and ethnic differences in job searching in urban centers. In A. O. O'Connor, C. Tilly, \& L. D. Bobo (Eds.), Urban inequality: Evidence from four cities: 341-371. New York: Russell Sage Foundation.

Fei, X. 1992 [1949].From the soil, the foundations of Chinese society. Berkeley, CA: University of California Press.

Fernandez, R. M., Castilla, E. J., \& Moore, P. 2000. Social capital at work: Networks and employment at a phone center. American Journal of Sociology, 105(5): 1288-1356.

Fried, M. H. 1953. Fabric of Chinese society: A study of the social life in a Chinese county seat. New York: Octagon Books.

Galenianos, M. 2014. Hiring through referrals. Journal of Economic Theory, 152: 304-323.

Gelfand, M. J., Erez, M., \& Aycan, Z. 2007. Cross-cultural organizational behavior. Annual Revieze of Psychology, 58: 479-514.

Gerber, T., \& Mayorova, O. 2010. Getting personal: Networks, institutions, and stratification in the Russian labor market, 1985-2001. American Journal of Sociology, 116(3): 855-904.

Gold, T. 1985. After comradeship: Personal relations in China since the cultural revolution. China Quarterly, 104(December): 657-675.

Granovetter, M. 1973. The strength of weak ties. American Journal of Sociology, 78(6): 13601380.

Granovetter, M. 1995. Getting a job: A study of contacts and careers. Chicago: University of Chicago Press.

Guthrie, D. 1998. The declining significance of guanxi in China's economic transition. The China Quarterly, 154(June): 254-282.

Hall, E. T. 1959. The silent language. New York: Doubleday.

Hanser, A. 2002. Youth job searches in urban China: The use of social connections in a changing labor market. In T. Gold, D. Guthrie, \& D. Wank (Eds.), Social connections in China: 137161. New York: Cambridge University Press.

Hellerstein, J. K., McInerney, M., \& Neumark, D. 2011. Neighbors and coworkers: The importance of residential labor market networks. Journal of Labor Economics, 29(4): 659-695.

Hewlett, S. A. 2013. Forget a mentor, find a sponsor: The new way to fast-track your career. Boston, MA: Harvard Business Review Press.

Hofstede, G. 1984. Culture's consequences: International difference in work related values. Beverly Hills, CA: Sage.

Hofstede, G. 1997. Culture and organizations: Software of the mind: Intercultural cooperation and its importance for survival. New York: McGraw-Hill.

Holzer, H. 1994. Black employment problems: New evidence, old questions. Journal of Policy Analysis \& Management, 13(4): 699-722.

Huang, X. 2008. Guanxi networks and job searches in China's emerging labour market: A qualitative investigation. Work, Employment, and Society, 22(3): 467-484.

Huo, Y. P., Huang, H.J., \& Napier, N. K. 2002. Divergence or convergence: A cross-national comparison of personnel selection practices. Human Resource Management, 41(1): 3144.

Hwang, K.-k. 1987. Face and favor: The Chinese power game. American Journal of Sociology, 92(4): $944-974$.

Ibarra, H. 1992. Homophily and differential returns: Sex differences in network structures and access in an advertising firm. Administrative Science Quarterly, 37(3): 422-438.

Ibarra, H. 1995. Race, opportunity, and diversity of social circles in managerial networks. The Academy of Management Journal, 38(3): 673-703.

Jackman, M. R. 1994. The velvet glove: Paternalism and conflict in gender, class, and race relations. Berkeley: University of California Press.

Jacobs, J. B. 1979. A preliminary model of particularistic ties in Chinese political alliances: KanChing and Kuan-Hsi in a rural Taiwanese township. The China Quarterly, 78(June): 237273.

King, A. Y.-c. 1985. The individual and group in Confucianism: A relational perspective. In D. J. Munro (Ed.), Individualism and holism: Studies in Confucian and Taoist values. Ann Arbor, MI: Center for Chinese Studies, University of Michigan.

Kipnis, A. 1997. Producing guanxi: Sentiment, self, and subculture in a north China village. Durham, NC: Duke University Press. 
Kitayama, S. 2002. Culture and basic psychological processes: Toward a system view of culture. Psychological Bulletin, 128(1): 89-96.

Korpi, T. 2001. Good friends in bad times? Social networks and job search among the unemployed in Sweden. Acta Sociologica, 44(2): 157-170.

Liang, S. 1986 [1949].The essential meanings of Chinese culture. Hong Kong: Zheng Zhong Press.

Liang, Z., Appleton, S., \& Song, L. 2016. Informal employment in China: Trends, patterns and determinants of entry. Institute for the Study of Labor (IZA), Unpublished Discussion Paper No. 10139 .

Lin, N. 1982. Social resources and instrumental action. In P. V. Marsden \& N. Lin (Eds.), Social structure and network analysis: 131-145. Beverly Hills, CA: Sage.

Lin, N. 1995. Local market socialism: Local corporation in action in rural China. Theory and Society, 24(3): 301-354.

Lin, N. 1999a. Social networks and status attainment. Annual Review of Sociology, 25: 467-487.

Lin, N. 1999b. Building a network theory of social capital. Connections, 22(1): 28-51.

Lin, N. 2001 a. Guanxi: A conceptual analysis. In A. So, N. Lin, \& D. Poston (Eds.), The Chinese triange of mainland, Taizuan, and Hong Kong: Comparative institutional analysis. Westport, CT: Greenwood.

Lin, N. 2001b. Social capital: A theory of social structure and action. Cambridge: Cambridge University Press.

Lin, N. 2011. Capitalism in China: A centrally managed capitalism (CMC) and its future. Management and Organization Review, 7(1): 63-96.

Lin, N., \& Bian, Y. 1991. Getting ahead in urban China. American Journal of Sociology, 97(3): 657-688.

Lin, N., Ensel, W. M., \& Vaughn, J. C. 1981. Social resources and strength of ties: Structural factors in occupational status attainment. American Sociological Revieze, 8(1): 393-405.

Lin, N., Fu, Y.-c., \& Chen, G.-j. J. 2013. Social capital and its institutional contingency: $A$ study of the United States, China and Taizean. Abingdon-on-Thames, UK: Routledge.

Lo, M.-C., \& Otis, E. M. 2003. Guanxi civility: Processes, potentials, and contingencies. Politcs \& Society, 31(1): 131-162.

Logan, J. R., \& Molotch, H. L. 1987. Urban fortunes: The political economy of place. Berkeley, CA: University of California Press.

Loury, L. D. 2006. Some contacts are more equal than others: Informal networks, job tenure, and wages. Journal of Labor Economics, 24(2): 299-318.

Lunding, F. S., Clements, C. E., \& Perkins, D. S. 1979. Everyone who makes it has a mentor. Harvard Business Revieze, 56: 89-101.

Luo, Y., Huang, Y., \& Wang, S. 2012. Guanxi and organizational performance: A meta-analysis. Management and Organization Review, 8(1): 139-172.

Ma, R., Huang, Y.-C., \& Shenkar, O. 2011. Social networks and opportunity recognition: A cultural comparison between Taiwan and the United States. Strategic Management Journal, 32(1 1): $1183-1205$.

Markus, H. R., \& Kitayama, S. 1991. Culture and the self: Implications for cognition, emotion, and motivation. Psychological Review, 98(2): 224-253.

Marsden, P. V., \& Hurlbert, J. S. 1988. Social resources and mobility outcomes: A replication and extension. Social Forces, 66(4): 1038-1059.

Massey, D. S. 2007. Categorically unequal: The American stratification system. New York: Russell Sage Foundation.

Massey, D. S., \& Denton, N. A. 1993. American apartheid: Segregation and the making of the underclass. Cambridge, MA: Harvard University Press.

McDonald, S., Lin, N., \& Ao, D. 2009. Networks of opportunity: Gender, race, and job leads. Social Problems, 56(3): 385-402.

McGuire, G. M. 2000. Gender, race, ethnicity, and networks: The factors affecting the status of employees' network members. Work \& Occupations, 27(4): 500-523.

McPherson, J. M., Smith-Lovin, L., \& Cook, J. M. 2001. Birds of a feather: Homophily in social networks. Annual Review of Sociology, 27: 415-444.

Mills, G. W. 1997. The racial contract. Ithaca, NY: Cornell University Press.

Mincer, J. 1974. Schooling, experience, and earnings. New York: Columbia University Press.

Mincer, J. 1997. The production of human capital and the life cycle of earnings: Variations on a theme. Journal of Labor Economics, 15(1): S26-S47. doi: 10.2307/2535400. 
Mizruchi, M. S., \& Brewster Stearns, L. 2002. Getting deals done: The use of social networks in bank decision making. American Sociological Revieze, 66(5): 647-672.

Nee, V. 1989. A theory of market transition: From redistribution to markets in state socialism. American Sociological Revieze, 54(5): 663-681.

Nee, V. 1991. Social inequalities in reforming state socialism: Between redistribution and markets in China. American Sociological Revieze, 56(3): 267-282.

Nee, V. 1992. Organizational dynamics of market transition: Hybrid forms, property rights, and mixed economy in China. Administrative Science Quarterly, 37(1): 1-27.

Nee, V. 1996. The emergence of a market society: Changing mechanisms of stratification in China. American Journal of Sociology, 101(4): 908-949.

Nee, V., \& Cao, Y. 1999. Path dependent societal transformation: Stratification in hybrid mixed economies. Theory and Society, 28(6): 799-834.

Nee, V., \& Matthews, R. 1996. Market transition and societal transformation in reforming state socialism. Annual Revieze of Sociology, 22: 401-435.

Nee, V., \& Opper, S. 2010. Political capital in a market economy. Social Forces, 88(5): 21052132.

Nisbett, R. E. 2003. The geography of thought: How Asians and Westerners think differently ... and why. New York: The Free Press.

Nisbett, R. E., Peng, K., Choi, I., \& Norenzayan, A. 2001. Culture and systems of thought: Holistic versus analytic cognition. Psychological Revieze, 108(2): 291-311.

Obukhova, E. 2012. Motivation vs. relevance: Using strong ties to find a job in China. Social Science Research, 41(3): 470-480.

Oi, J. C. 1999. Rural China takes off: Institutional foundations of economic reform. Berkeley, CA: University of California Press.

Parish, W. L., \& Michelson, E. 1996. Politics and markets: Dual transformations. American Journal of Sociology, 101(4): 1042-1059.

Portes, A. 1998. Social capital: Its origins and applications in modern sociology. Annual Revieze of Sociology, 24(1): 1-24.

Putnam, R. 2000. Bozling alone: The collapse and revival of American community. New York: Simon \& Schuster.

Qi, Xiaoying. 2013. Guanxi, social capital theory and beyond: Toward a globalized social science. The British Journal of Sociology, 64(2): 308-324.

Reskin, B. 2000. Getting it right: Sex and race inequality in work organizations. Annual Revieze of Sociology, 26: 707-709.

Rona-Tas, A. 1994. The first shall be last: Entrepreneurship and communist cadres in the transition from socialism. American Journal of Sociology, 100(1): 40-69.

Royster, D. A. 2003. Race and the invisible hand: How white networks exclude black men from blue-collar jobs. Los Angeles: University of California Press.

Schmutte, I. M. 2016a. Labor markets with endogenous job referral networks: Theory and empirical evidence. Labour Economics, 42:30-42.

Schmutte, I. M. 2016b. How do social networks affect labor markets. IZA World of Labor, 304.

Schneider, M., Teske, P., Roch, G., \& Marschall, C. 1997. Networks to nowhere: Segregation and stratification in networks of information about schools. American Political Science Revieze, 41(4): 1201-1223.

Seidel, M.-D., Polzer, J. T., \& Stewart, K. J. 2000. Friends in high places: The effects of social networks on discrimination in salary negotiations. Administrative Science Quarterly, 45(1): 1-24

Sharone, O. 2014. Social capital activation and job searching: Embedding the use of weak ties in the American institutional context. Work and Occupations, 41(4): 409-439.

Sidanius, J., \& Pratto, F. 1999. Social dominance: An intergroup theory of social hierarchy and oppression. Cambridge: Cambridge University Press.

Smith-Lovin, L., \& Miller McPherson, J. 1993. You are who you know: A network approach to gender. 223-51 In P. England (Ed.), Theory on gender - Feminism on theory, social institutions and social change: 223-251. Hawthorne: Aldine de Gruyere.

Smith, J. A., Smith-Lovin, L., \& Miller McPherson, J. 2014. Social distance in the United States: Sex, race, religion, age, and education homophily among confidants, 1985 to 2004. American Sociological Reviere, 79(3): 432-456.

Smith, R. A. 2002. Race, gender, and authority in the workplace: Theory and research. Anmual Revieze of Sociology, 28: 509-542. 
Son, J., \& Lin, N. 2012. Network diversity, contact diversity, and status attainment. Social Networks, 34(4): 601-613.

Stainback, K., \& Tomaskovic-Devey, D. 2012. Documenting desegregation: Racial and gender segregation in private-sector employment since the Civil Rights Act. New York: Russell Sage Foundation.

Thomas, D. A. 2001. The truth about mentoring minorities: Race matters. Harvard Business Revieze, 79(4): 99-107.

Tian, F. F., \& Lin, N. 2016. Weak ties, strong ties, and job mobility in urban China, 1978-2008. Social Networks, 44(January): 117-129.

Tilly, G. 1998. Durable inequality. Berkeley: University of California Press.

Triandis, H. G. 1995. Individualism and collectivisim. Boulder, CO: Westview Press.

Tsui, A. S., \& Farh, J.-L. L. 1997. Where guanxi matters: Relational demography and guanxi in the Chinese context. Work and Occupations, 24(1): 56-79.

Tsui, A. S., Nifadkar, S. S., \& Ou, A. Y. 2007. Cross-national, cross-cultural organizational behavior research: Advances, gaps, and recommendations. Journal of Management, 33(3): 426-478.

Uzzi, B. 1999. Embeddedness in the making of financial capital: How social relations and networks benefit firms seeking financing. American Sociological Revieze, 64(4): 481-505.

Vogel, E. F. 1965. From friendship to comradeship: The change in personal relations in communist China. The China Quarterly, 21(January-March): 46-60.

Walder, A. G. 1986. Communist neo-traditionalism: Work and authority in Chinese industry. Berkeley, CA: University of California Press.

Walder, A. G. 1996. Markets and inequality in transitional economies: Toward testable theories. American Journal of Sociology, 101(4): 1060-1073.

Walder, A. G. 2003. Elite opportunity in transitional economies. American Sociological Revieze, 68(6): 899-916.

Walder, A. G., Luo, T., \& Wang, D. 2013. Social stratification in transitional economies: Property rights and the structure of markets. Theory and Society, 42(6): 561-588.

Waldinger, R. 1997. Social capital or social closure? Immigrant networks in the labor market. Paper presented at the Lewis Center for Regional Policy Studies, Los Angeles.

Weber, M. 1968. Economy and society. Translated by G. Roth \& G. Wittich. New York: Bedminister Press.

Whyte, M. K., \& Parish, W. L. 1984. Urban life in China. Chicago, IL: University of Chicago Press.

Wu, X., \& Treiman, D. J. 2004. The household registration system and social stratification in China, 1955-1996. Demography, 41(2): 363-383.

Yakubovic, Y. 2005. Weak ties, information, and influence: How workers find jobs in a local Russian labor market. American Sociological Revieze, 70(3): 408-421.

Yang, M. M.-h. 1994. Gifts, favors, and banquets: The art of social relationships in China. Ithaca, NY: Cornell University Press.

Yang, M. M.-h. 2002. The resilience of guanxi and its new deployments: A critique of some new guanxi scholarship. The China Quarterly, 170(June): 459-476.

Zhao, W. 2013. Social networks, job search and income disparity in a transitional economy. Research in the Sociology of Work, 24: 104-124.

Zhou, X. 2000. Economic transformation and income inequality in urban China: Evidence from panel data. American Journal of Sociology, 105(4): 1135-1174.

Zhou, X., Li, Q., Zhao, W., \& Cai, H. 2003. Embeddedness and contractual relationships in China's transitional economy. American Sociological Revieze, 68(1): 75-102.

Nancy DiTomaso (nancy.ditomaso@rutgers.edu) is Distinguished Professor of Management and Global Business at Rutgers Business School-Newark and New Brunswick, USA. Her book, The American Non-dilemma, won the C. Wright Mills Award and was Runner Up for the George R. Terry Book Award. She won the 2016 Sage Award for Scholarly Achievement given by the Academy of Management Division on Gender and Diversity. She has published over 60 
research papers and 5 other books. Her research addresses issues of diversity, culture, and inequality.

Yanjie Bian (bianx001@umn.edu) is Professor of Sociology at University of Minnesota, USA. Concurrently, he is Director of the Institute for Empirical Social Science Research at Xi'an Jiaotong University, China. He is a co-founder (with Professor Li Lulu) of the Chinese General Social Survey, which is a public data archive available to domestic and international scholars. Author of 14 books and more than 140 research articles on topics of China's social stratification, social networks, and institutional change, Dr. Bian's current projects include the development of the sociology of guanxi, a panel study about networks and jobs in Chinese cities, and East Asian social networks. He was recognized as one of the 2014, 2015, and 2016 Elsevier most-cited Chinese researchers in social science.

Manuscript received: February 6, 2017

Final version accepted: November 7, 2017 (number of revisions - 1)

Accepted by: $\quad$ Editor-in-Chief Arie Y. Lewin 